\title{
Green Hotel Resilience Due to Covid-19 Pandemic: Case Study at Greenhost Boutique Hotel Yogyakarta
}

\author{
Aisha Wai Yasmina ${ }^{1 *}$, Andre Noevi Rahmanto ${ }^{2}$, Albert Muhammad Isrun Naini ${ }^{3}$ \\ ${ }^{1,2,3}$ Graduate Program in Communication, Faculty of Social and Political Science, ${ }^{3}$ Universtias Sebelas Maret Surakarta, \\ Indonesia \\ *Corresponding author. Email: aishawai@student.uns.ac.id
}

\begin{abstract}
It is a big hit for the world since Covid-19 pandemic appears. The pandemic presents a crisis for many sectors, and one of which is the hospitality tourism. The Special Region of Yogyakarta, which relies its economic wheels on this sector, is one of the destinations of the tourism city in Indonesia which is, no exception, affected by the outbreak. Thousands of hotels in Yogyakarta have experienced temporary closures but resumed their business. The crisis has forced the hotel industry to implement crisis communication to survive due to the Covid-19 pandemic not to be missed the strong brand in eco-friendly hotel. The objective of this study is to investigate how the crisis communication process in Covid-19 Pandemic is carried out by Greenhost Boutique Hotel with Environmental Marketing Communication that has been implemented. This research used a qualitative descriptive research with case study method. Its data were collected through in-depth interview, observation, and supporting documents. The results of this study indicate that the Covid-19 has caused the crisis that Greenhost Boutique Hotel is a victim of the crisis and has difficulty in determining a definite strategy to deal with the crisis due to the confusion of information about the pandemic. The role of the government, especially the Ministry of Tourism and Creative Economy, in responding to the Covid-19 crisis, is very crucial in overcoming the crisis. One of the strategies done by Greenhost Boutique Hotel is the \#newgreen and \#newnormal campaign in response to the crisis with a strong brand identity of Eco-Conscious hotels so that hotels can survive during the crisis.
\end{abstract}

Keywords: Crisis Communication, Hospitality, Covid-19 Pandemic, Eco-Conscious.

\section{INTRODUCTION}

Climate change and numerous natural disasters caused by irresponsible human actions on environment have made environmental sustainability a serious issue. However, the presence of the Covid-19 Pandemic has been a tremendous shock for the entire world. The whole world is experiencing an extraordinary crisis in various sectors, especially in tourism. Based on the data of WHO, the pandemic has been found since November 2019. It was was declared worldwide on March $11^{\text {th }}$, 2020 (https://www.worldometers.info/coronavirus) [1]. Sharma and Nicolau in Pongsakurnrungsilp (2021) et. al. predict that all sectors in the tourism industry will inevitably lose value [2]. The tourism industry is the main pillar that supports the economy of several regions in Indonesia, such as Bali and Yogyakarta. Ac clearly shown by the data of the Indonesian Central Bureau of Statistics, the number of foreign tourists visiting Yogyakarta during 2019 reached 16.3 million, and $12 \%$ of them came from China. However, in 2020 the number of tourists both domestic and foreign ones, dropped dramatically to 1.3 million with a total of 40,570 foreign tourists (https://rri.co.id/yogyakarta/sosial/pariwisata/1004819/tahun -2020-kunjungan-wisata-jogja-capai-1-juta-wisatawan) [3].

As reported by Radarjogja.jawapos, Chief of Indonesian Hotel and Restaurant Association in the Special Region of Yogakarta, Deddy Pranowo Eryono, said that the loss of consumers and production costs experienced by hotels and restaurants in Yogyakarta was predicted to reach Rp240 billion. The loss was dominated by the hotels in the form of cancellation of occupancy since the outbreak of Covid-19. It can even be said that the hotel occupancy rate is zero percent (https://radarjogja.jawapos.com/bisnis/2020/04/27/phri-dijklaim-kerugian-pasca-covid-19-mencapai-rp-240-miliar/) [4]. Similar conditions have occurred in Taiwan during the SARS (Severe Acute Respiratory Syndrome) pandemic which caused the tourism industry to suffer losses [5]. One of the previous studies showed that overreaction to the pandemic is the reason for the collapse of Asian tourism. However, the strategy in the SARS crisis cannot be equated with that in the Covid-19 because the crisis still continues to this day. The study also revealed a gap in understanding how to minimize the impact of a pandemic. It is rarely disclosed, and this requires the attention of the planned strategy [6]. The results of previous research interviews in Taiwan revealed that it is 
important to help the tourism industry to succeed in going through the 'hibernation' period and to have sufficient energy to bounce back [7].

In contrast to the research conducted by Ketter and Avraham (2021) in the active crisis stage, destinations face a crisis and are forced to shift from proactive marketing to reactive marketing and mitigation by adopting the marketing strategies of hope and inspiration, human brotherhood and longing, nostalgia to keep potential visitors on the destination marketing channel as to keep the destination in front of their minds or as one of the top of mind. One of the strategies is reached through several video campaigns on Youtube for 40 developed countries that are most frequently visited with the keyword \#Stayhome today so we can \#TravelTomorrow [8].

This research was different from the previous ones in term of the object of research. Its object was Greenhost Boutique Hotel Prawirotaman, a hotel from a developing country with a specific hotel specification i.e. brand which is concerned about environment or green hotel (eco-conscious). This specialty has a distinct contribution in this research. The ecoconscious branding strategy has run for a long time so that it is not a special strategy to deal with the Covid-19 pandemic crisis. As the impacts, the strategy results in a strong brand identity which can be used as one of the strategies to respond the Covid-19 pandemic crisis. The objective of this research is to disclose the handling of how Greenhost Boutique Hotel survives in the Covid-19 pandemic crisis viewed from the theory of crisis communication management

\section{LITERATURE REVIEW}

\subsection{Crisis Communication}

According to Wasesa (2010) crisis communication is a strategy to communicate what it wants to say and to do and what an organization has done in responding to a crisis [9]. Crisis as a process was conveyed by G. Harrison $(2005: 11)$ when conducting research on communication strategies as the basis for implementing crisis management. A crisis is an event that may have a negative impact on the organization. Quick and appropriate decisions need to be made so as not to affect the overall operations of the organization. Decisionmaking definitely requires bold step information processing to minimize unwanted consequences [10]. Coombs (2007) discusses that a crisis tends to be a situation that produces negative effects that affect the organization and its publics, its products, and its reputation. There are three strategies in crisis communication i.e. identifying sources of information, gathering information, and analyzing information [11]. Coombs (2010) states that crisis management can be divided into three stages, namely pre-crisis, crisis response, and postcrisis [12].

\subsubsection{Pre-Crisis}

This stage focuses on the prevention and preparation before a crisis. There are several steps that management can take in preparation for the crisis i.e. have a crisis management plan which is updated annually, have a well-trained crisis management team, test the crisis management plan and team at least once a year; and (d) prepare multiple crisis management messages including for online media and blueprints for crisis statements.

\subsubsection{Crisis Response}

This stage is carried out when management must overcome the emerging crisis. Coombs (2007) states that there are four broad categories in responding to a crisis i.e. denying, diminishing, rebuilding, and reinforcing. Denying strategies are better for dealing with rumors or issues. Crises caused by accidents or past history are usually managed with a minimization strategy. Rebuilding strategies are usually used to anticipate crises, and reinforcing strategies include compensation, apologies, corrective actions and benefits.

\subsubsection{Post-Crisis}

Last stage is where management evaluates to anticipate crises that could come again in the future and fulfills commitments during times of crisis as well as follows up on information. A good crisis management strategy must also consider the steps from when the issue begins to develop until the crisis ends. When a crisis occurs, crisis communication also needs to be designed by considering the communication model, message strategy, organizational publics and organizational goals.

\section{METHOD}

This research used the descriptive qualitative research with a case study method. This is relevant to the crisis situation hitting Greenhost Boutique Hotel Yogyakarta with a specific case during the Covid-19 Pandemic. This research explained in detail step by step the crisis communication process carried out by the hotel with green hotel as the brand identity. Its data consisted of primary and secondary data. The former were collected through in-depth interviews with informants by face-to-face technique in order to obtain complete and in-depth data. This study used face-to-face or telephone interview techniques with the General Manager, Head of Human Resources, Sales Marketing and Marketing Communication for the period January-August 2021. The latter were collected by conducting literature studies and content analysis of the documents from the object of research either from the results of previous research, literature reviews or from operational reports of the research object.

\section{FINDINGS \& DISCUSSION}

\subsection{Crisis Communication}

Greenhost Boutique Hotel claims that it cares about the environment. It is well known as an eco-conscious hotel, which is the brand identity of the hotel. The hotel which is a 
member of of the AYOM Group is located on Jalan Prawirotaman Yogyakarta, known as "Kampung Bule". It is popular because its understanding of environmental care is better understood and interpreted by foreign tourists than domestic ones. The eco-concious concept is implemented in various aspects from its operations to its promotions. Some simple examples of implementation include the use of energysaving lamps, an open-air lobby where air circulation tends to be cleaner and the entire lobby surrounded by green plants that help improve air circulation, big windows in all room for better air circulations, and the rooftop which is equipped with a hydroponic garden. This concept benefits the hotel in times of crisis because it has paid attention to the elements of health and cleanliness for the brand recall.

According to Coombs in Prayudi (2016) crisis communication is an action or response to a crisis. [13] Vivie Elizabeth, General Manager of Greenhost Boutique Hotel stated that in March 2020 news about Covid-19 was found in Wuhan China. Since then the hotel occupancy has been affected, and its occupancy rate has gradually decreased. One of the reasons is its location which is on Jalan Prawirotaman, where $80 \%$ of the visitors are foreign tourists with the largest market coming from Italy, Spain, America and Singapore. Signs of the declining occupancy are early signs of a crisis. However, according to Vivie Elizabeth, there was no specific response in dealing with this issue because the circulating information was confusing and caused a confusion to take a stand inspite of its advantageous eco-concious brand position that can be empowered as one of the strategies to deal with this crisis.

Three stages in a crisis management according to Coombs (2010) are pre-crisis, crisis response and post-crisis. The results of interviews with the respondents show that there has been no special preparation (pre-crisis strategy) taken by the hotel to deal with the outbreak which was reported when it hit Wuhan. Although the occupancy rate experienced no drastic decline, the hotel did not have any idea that it would become a prolonged crisis. As a result, the hotel did not prepare a special team to handle this crisis in the beginning of 2020. Unlike the case with major forces such as fires, earthquakes, and even acts of terrorism, a crisis team has been formed and well trained, consisting of General Manager that is responsible for everything, Marketing Communication Division that has the right to diseminate information to external parties, and Human Resource Manager as the party responsible for internal communication.

\subsubsection{Pre-Crisis}

The article in Thailand entitled "The Art of Survival: Tourism Business in Thailand Recovering from Covid-19 through Brand Management" states that if you have a strong brand, you will continue to survive. Meanwhile, based on the report of "Information and Impact on Covid-19" which was updated on April 21, 2020, at least 1,674-star hotels temporarily stopped operating. However, at that time the occupancy of Greenhost Boutique Hotel was not lower than other hotels. Prior to the closure, its occupancy rate was still $20 \%$. This could happen due to its strong brand amidst the absence of a planned pre-crisis strategy.

\subsubsection{Crisis Response}

The confusion of information and the uncertain implementation of travel regulations for travelers by the government became issues inhibiting the determination of next strategies to deal with the crisis. At that time, to respond the crisis, only a step of mandatory was taken by the General Manager to build a team i.e. the " GH's Covid-19 Risk Committee" which was formed through the Whatsapp Group. The team was commanded by the Human Resource Manager, Head of Internal Department related to cleanliness and security such as housekeeping, food and beverage, engineering, Head of External Department, Marketing Communication Division, Sales Division, E-Commerce Division, and Security Division. The team was responsible for collecting the latest information on the outbreak and processing the messages to the public in accordance with the Greenhost Hotel brand. The team was estabilshed spontaneously. The crisis situation forced the hotel to take steps to respond the crisis promptly. However, there was not any firm strategy until the announcement of the lockdown to be carried out in Indonesia, and hotel occupancy continued to decline up to $15 \%$ per day.

\subsubsection{Deny Strategies}

The strategy of attacking an organization (Attack the Accuser) or looking for a scapegoat (Scapegoat) [14] is not carried out by Greenhost Boutique Hotel. However, the hotel initially denied that there would be a crisis, which is evidenced by the absence of a pre-crisis strategy. Although not explicitly denying the Covid-19, the hotel considered that there would be no projection of a crisis to happen. Thus, a denial strategy was not entirely used in this crisis situation.

\subsubsection{Justification}

Justification is usually done by showing evidence or data that support the statement. In the end, Greenhost Boutique Hotel stated that occupancy was decreasing, and the hotel would continue to struggle with operational costs if it continued to run. The Sales Marketing staff, Novi Kristianti said,

"Our main target market is not from Indonesia, so from the beginning of the news of Covid-19, gradually the occupancy dropped drastically in the beginning of 2020 , every day reaching $80 \%$ (although) in April it only reached $14 \%$ and continued to decline again. We can't close our eyes and force ourselves to keep looking for a market that doesn't exist, and we admit that the effects of the Covid-19 on 
hospitality are quite pronounced. Prospective customers or some direct messages that enter our social media also state that they are very afraid of doing activities outside the home. One of the reasons is that there are many different issues regarding the effects of Covid-19 itself. There is no definite picture of what kind of storm or disease it is, so there is no sense of certainty in the society or travelers."

Although there was no official statement from the government in dealing with the Covid-19, especially for the tourism sector, the Covid-19 team had compiled several major force strategies to respond to this crisis, one of which was by temporarily closing and not having any activities at hotels including restaurants and spas when the condition was getting worse.

\subsubsection{Rebuild Strategies}

\section{a. Compensation}

This strategy seeks to change the public's perception of the organization by accepting the fact that there is really a crisis. In this strategy, Greenhost Boutique Hotel aspired to create the perception that the hotel also participates in an effort of breaking the chain of the Covid-19 virus spread, which is very risky by closing the hotel. A compensation strategy was also carried out on guests who had booked on the date after the hotel closing. All guests who had ordered could refund 100\% of their money without any deductions.

\section{b. Apology}

This strategy is an apology from the organization to the public. Greenhost Boutique Hotel apologized for the closure of the hotel due to the Covid-19 Pandemic and could not operate at all. All apologies were uploaded on the hotel's official social media and released on several local Yogyakarta news outlets. After several hotels in Yogyakarta had stopped their operations for a while, the government then decided to do a lockdown in the Yogyakarta area, and it was forbidden to carry out activities outside the home.

\subsubsection{Reinforcing/Blostering Strategies}

\section{a. Reminder}

Greenhost Boutique Hotel has strived to seek public support by using various means and to make the public remember what has been done to create a positive image. Among the messages conveyed is that Greenhost Boutique Hotel is a hotel that cares about the environment with several concepts that have been implemented so far, either operationally or promotionally. The Greenhost Boutique Hotel brand entity that was built before the crisis really helps in the management of this crisis communication. As a green hotel, it cares about the environment that associates the perception to the community that cleanliness and health are an important part of its brand entity i.e. a green or ecoconscious hotel.

\section{b. Ingratiation}

It is a strategy to take heart by praising stakeholders or reminding them of good deeds that have been done by the organization. In this strategy, Greenhost Boutique Hotel on its social media, especially Instagram, brings back memories of guests who have stayed or vacationed in Yogyakarta by creating a sense of "want to come back" during the holiday. Memories of traveling before Covid-19 become one of the messages conveyed. Marketing Communication staff Dita Retno stated that many guests responded to the content and said they wanted to go back on vacation to Yogyakarta and to stay at the Greenhost Boutique Hotel. However, there is no courage to travel because of the increasing amount of news regarding travel restrictions and documents which are quite difficult to fulfill prior to travelling.

\section{c. Victimage}

It is clear that Greenhost Boutique Hotel is a victim of the Covid-19 pandemic crisis. Krisna P. Atmaji Human Resources Corporate stated,

"Greenhost Boutique Hotel is "forced" to get used to the new normal. Greenhost Boutique Hotel, which basically states that it tries to reduce the use of plastic in its operations as one of the value of green hotel, has to reduce the idealism because each meal must be covered with cling wrap and all house keeping's and kitchen employees are required to use disposable latex gloves and must wash their hands before and after cleaning. Before the Covid-19 pandemic, breakfast was served as a buffet. However, to apply the health protocol strictly, buffet will be provided if the occupancy is more than $50 \%$ with no self-service. Spa services should be closed for the hotel's purpose to reduce body contact with one another. Until June 2021, spa services remained closed. The use of swimming pools is also a major concern in this new custom. No more than 5 people can use the pool at once and must take turns. This is done to reduce the density in the swimming pool. Housekeeping tasks also become more complex, and many adjustments are made as to survive this crisis."

All changes in normal behavior during the Covid-19 pandemic are all used as contents or messages given to the public with the aim of returning trust and creating a sense of safety when staying at Greenhost Boutique Hotel. All information is informed through digital media such as social media, online media, conventional $\mathrm{TV}$ and/or radio, TV Room, Lobby TV to TV Lift.

\subsubsection{Post-Crisis}

The post-crisis process is indeed an evaluation to anticipate crises that may emerge again in the future and to respond better to crises. This Covid-19 crisis is exceptional compared to other crises as it has not ended until now. However, according to sales marketing of the hotel, at the end of 2020 after the hotel reopened, its occupancy was very good. People started doing some staycation activities, but the hotel did not to promote meetings and weddings at the hotel. In the post-crisis process, special campaigns for \#newgreen 
and \#newnormal began to be often conveyed in several media. The message was a statement that the Hotel is ready to receive guests back with very strict health protocols. Information on tightening health protocols was all listed on hotel social media, TV rooms, TV Lobby and TV Lifts with the \#newnormal \#newgreen campaign.

Greenhost Boutique Hotel GM explained,

"We have implemented all health protocols, and one of the advantages of our hotel is that it has a green concept with open spaces. This is one of the considerations of the customers, especially the issue which is currently circulating that Covid-19 can spread air-bore even though it has not been proven by research. Greenhost Boutique Hotel has been certified CHSE which is one of the programs from the Ministry of Tourism and Creative Economy to revive the tourism sector."

Cleanliness, Health, Safety, Enviroment (CHSE) certification from the Ministry of Tourism and Creative Economy is the starting point for the \#newgreen campaign from Greenhost Boutique Hotel. It is unfortunate that the Ministry of Tourism and Creative Economy does not provide further promotions or solutions for hotels to bounce back. Travellers do not comprehensively understand about CHSE certification. Only tourism actors understand the meaning and function of the certification. The effectiveness of solutions from the government, especially from the Ministry of Tourism and Creative Economy, needs to be reviewed. Although the \#newgreen campaign has not been specifically conveyed either, the strategy has been assisted by the greenhotel image which is onwed by Greenhost Boutique Hotel and which has been attached so far before crisis. Thus, \#newgreen \#newnormal is just an information emphasis, especially in the domestic market.

\section{CONCLUSION}

Not having a managed-well pre-crisis strategy for Greenhost Boutique Hotel doesn't make its business crumbled due to the Covid-19 crisis. The hotel has the resilience because of its strong eco-concious brand image. Crisis communication management in the Covid-19 era is very dependent on digitalization media such as social media and several digital devices such as TV Rooms, Lobby TVs to TV Lifts to deliver the message. The media canals have been in one way with the green concept i.e. paperless operations, which have been implemented before. The dissemination of information through the media is very fast, giving rise to certain attributions to the crisis.

Greenhost Boutique Hotel has tried to communicate the Covid-19 crisis to the public with various things on social media and releases that it has made to respond to new behaviours or the new normal era. However, it is unfortunate that the consistency in disseminating messages regarding \#newgreen and \#newnormal campaign is not explained in detail on social media or releases. Even the dissemination only appeared once after the hotel was declared to be reopening, and it only relies on a previously formed brand image. Providing detailed information on CHSE certification can be used as a strategy by linking it with green communication. It is not only limited to displaying a photo of a certificate and relying on a statement that the hotel has passed the certification, but also projected to more elaboration of its excellences. In general, Greenhost Boutique Hotel has carried out good crisis communication in the first wave. It could restore its occupancy steadily in May-June 2021 on average above $60 \%$ occupancy in working days and $100 \%$ occupancy in weekends.

Uncertainty in information and confusing governmental regulations in responding to or in providing the tourism sector with solutions to encounter the Covid-19 pandemic are the main inhibiting factors for doing actions. Meanwhile, a strong brand, especially regarding the sustainability of the environment, is one of the reasons the hotel can survive during the crisis.

\section{REFERENCES}

[1] World Meters. (2021, Agust 3). Covid-19 Corona Virus Pandemic. Retrieved August 10, 2021 from Worldmeters.info Website: https://www.worldometers.info/coronavirus

[2] Pongsakornrungsilp,S.; Pongsakornrungsilp, P.; Kumar, V.; Maswongssa, B. The Art of Survival: Tourism Businesses in Thailand Recovering from COVID-19 through Brand Management. Sustainability 2021, DOI https://doi.org/ 10.3390/su13126690

[3] Parwanto, Dyan. (2021, March 24). Tahun 2020 Kunjungan Wisata Jogja Capai 1 Juta Wisatawan. Retrieved August 10, 2021 from rri.co.id. Website: https://rri.co.id/yogyakarta/sosial/pariwisata/1004819/t ahun-2020-kunjungan-wisata-jogja-capai-1-jutawisatawan

[4] Radar Jogja (2020, April 27). PHRI DIJ Klaim Kerugian Pasca Covid-19 Mencapai Rp 240 Miliar. Retrieved August 10, 2021 from Radar Jogja. Website: https://radarjogja.jawapos.com/bisnis/2020/04/27/phridij-klaim-kerugian-pasca-covid-19-mencapai-rp-240$\underline{\text { miliar/ }}$

[5] Ritchie, Brent W; Dorrell, Humphrey; Miller, Daniela; Miller, Graham A. Crisis Communication and Recovery for the Tourism Industry: Lessons from the 2001 Foot and Mouth Disease Outbreak in the United Kingdom. Journal of Travel \& Tourism Marketing Janury 2004, DOI: $10.1300 / J 073 v 15 n 02 \_11$

[6] Kerlin, Karen; Bussy, de Nigel. 2006. Expecting The Unexpected: Crisis Communication Preparedness in The Tourism Industry. Asia Pacific Public Relations Journal 6 (1): 63-78. DOI: 20.500.11937/14612 
[7] Shih-Shuo Yeh (2021) Tourism recovery strategy against COVID-19 pandemic, Tourism Recreation Research, 46:2, 188-194, DOI: 10.1080/02508281.2020.1805933

[8] Ketter, Eran; Avraham, Eli (2021): \#StayHome today so we can \#TravelTomorrow: tourism destinations' digital marketing strategies during the Covid-19 pandemic, Journal of Travel \& Tourism Marketing, DOI: $10.1080 / 10548408.2021 .1921670$

[9] Wasesa, Silih A.; Macnamara, Jim. (2010). Strategi Public Relations. Jakarta: Gramedia Pustaka Utama

[10] Harrison, G. (2005). Communication Strategies as a Basis for Crisis Management Including Use of the Internet as a Delivery Platform. Dissertation. Georgia: Georgia State University

[11] Coombs, W.T. (2007). Parameters for Crisis Communication. In W.T. Coombs \& S.J. Holladay (Eds.), The Handbook of Crisis Communication. West Sussex: Wiley-Blackwell.

[12] Coombs, W.T. (2010). Parameters for Crisis Communication. In W.T. Coombs \& S.J. Holladay (Eds.), The Handbook of Crisis Communication. West Sussex: Wiley-Blackwell.

[13] Prayudi. 2016. Manajemen Isu \& Krisis.Yogyakarta: LPPM UPN Veteran Yogyakarta.

[14] Putri, Astri.W; Sutopo; Rahmanto, Andre. N. Ministry of Agriculture's Crisis Communication on PT IBU RICE warehouse case. Jurnal Studi Komunikasi Vol. 23 No. 1 (juni 2019) hal: 43-70 